\title{
Empirical Study of the Effect of Participation of Budget in Managerial Performance
}

\author{
Arifin $^{1}$, Gagaring Pagalung² \\ ${ }^{1}$ Faculty of Economics, University of Ichsan Gorontalo \\ e-mail: arifin.unisan@gmail.com \\ ${ }^{2}$ Faculty of Economics and Business Has anuddin University Makassar \\ e-mail : gpagalung@yahoo.com
}

\begin{abstract}
This literature study aims to build and construct conception more strongly based on empirical studies that have been conducted so that it can describe how the effects of budgeting participation in improving managerial performance. In this study the author uses a literature study approach based on empirical studies or studies in several international journals relating to budgetary participation with performance. The review of this article can be concluded that budgetary participation can provide a positive role in managerial performance. Butbudget participation is not the only factor that can improve managerial performance butbudget participation can be moderated or mediated with other variables such as psychological capital, Job relevant Information, knowledge and competencies, leadership style, motivation, and others.
\end{abstract}

Keyword- Budget Participation, Managerial Performance.

\section{INTRODUCTION}

Regional autonomy is no longer just carrying out instructions from the center, but regions are really expected to have the freedom to increase creativity in developing the potential that during the era of autonomy can be said to be isolated (Mardiasmo, 2002). There fore the regional government is expected to be independent, reduce dependence on the central government, both on financing issues and related to the ability of regional financial management.

Regional governments are expected to get closer to various public service activities in order to increase the level of public trust. One important aspect in the framework of implementing regional autonomy and decentralization is the issue of regional finance and regional budgets. To that end, in order to produce a budget structure that is in accordance with normative expectations and conditions, the regional expenditure budget is essentially a quantitative elaboration of the goals and objectives of the regional government and the main tasks and functions of the work unit must be arranged in a structure that is oriented towards achieving certain levels of performance. .

Mardiasmo (2002) states that a government's accountability and the influence of regional autonomy is one of the demands of the community, there fore regional autonomy brings a change in the budget system from the traditional budget system to the budget system with an approach to the public interest (New Public Management). The emphasis of this approach is comprehensive and integrated decentralization and management submission on value for money. This change has also encouraged the government to develop a more systematic approach to budget planning usingperformance budgeting techniques, Zero Based Budgeting (ZBB), and Planning, Programing, and Budgeting Systems (PPBS) which focus on planning and controlling.

Public sector budgeting is an instrument of accountability for the management of public funds and the implementation of programs financed from public money. Public sector budgeting is related to the process of determining the amount of funds allocated for each program and activity in monetary units. The budgeting process emphasizes the Buttom-up Planning approach, there fore the need for subordinates is given the opportunity to participate in the budget preparation process because according to him participation in budgeting is believed to improve the performance of local government officials.

Murray (1990); Chow/ Cooper/ Waller ( 1988 ) and Lau/ Buckland (2001) state that budgetary participation (BP) means the participation of top managers and subordinates for the process of determining resources in using their own activities and operations. From a psychological and cognitive perspective, there are two basic benefits of subordinate participation in budget settings. First, because identification and ego involvement with budget goals, participation related to performance and so on, leads to increased motivation and commitment to the budget. Second, because it increases the flow of 
information between superiors and subordinates, budget participation (BP) leads to higher quality decisions. From this perspective, participation leads to higher motivation, higher commitment, higher quality decisions and therefore higher performance.

But in the current condition the author tries to propose that there are or no additional factors that influence the relationship between participation and performance. This paper aims to ask about the interrelated aspects of budget participation and the performance of organizational commitment as important variables that influence this linkage. Study conducted by Alan s. Dunk (1989), Brownell \& Hirst (1986) have become the latest step in a series of studies answering the question of whether or not superior manager evaluation styles have an impact on the relationship between participation and subordinate manager performance. Hopwood (1972) speculates in examining cost center managers that evaluation styles focusing

on accountingmeasures will have a negative effect on managerial performance. Otley (1978) states that leadership style emphasizes the achievement of the budget associated with greater levels of performance. Brownell (1982), in an effort to reconcile Hopwood (1972) and Otley (1978), found that high budgets were effective emphasis on managerial performance in conditions of high budget participation but not under low participation.

This literature review aims to show empirically more strongly based on studies that have been conducted. In this study, researchers map several articles or studies related to budget participation with managerial performance published in international journals. Further specifically, researchers examined the empirical article article relating to the role of budgetary participation on managerial performance

\section{CONCEPTUAL STUDY OF MANAGERIAL PERFORMANCE}

Wong-On-Winget, et.al., (2010) states that managerial performance is the result of the work of each member of the organization in managerial activities such as planning, investigation, coordination, supervision, staff, negotiation and representation. Anthony and Govindarajan (2001) state that managerial performance shows the ability of managers' performance in management to function in management functions for activities as their primary responsibility. Performance tends to increase when managers use the budget to allocate resources. Adequate allocation of resources for subordinates will make the performance of subordinates more productive. (Fis her et. Al., 2002).

Almasi (2015), Ang et al., (2007), states that performance is a set of actions and activities, achieved by employees to achieve organizational goals that have been determined and consists of several indicators such as job satisfaction, commitment, ability, motivation, efficiency.

\section{CONCEPTUAL STUDY OF BUDGET PARTICIPATION}

Hariyanti, et.al (2015) states that the budget is one of the instruments to evaluate the performance of managers. Based on behavioral planning theory that the involvement of managers in the budgeting process is the behavior that is believed by managers to be given a positive impact in the form of performance improvements. The performance of each member of an organization in managerial activities is also known as managerial performance including: planning, preparation, execution of tasks and functions realized in the form of budget arrangements. One of the controlling instrument organizations is the budget which is one of the important aspects in the management accounting perspective (Hansen and Mowen, 2000).

The budget is arranged in a certain period of time as a guide in carrying out the organization of operational activities and as a means to evaluate performance. Based on motivation theory and the theory of self-determination, individuals have certain behaviors because there is a motivation behind their behavior. According to motivation theory, the behavior of managers to participate in preparing and setting budgets is caused by motivation. Motivation can be either intrinsic motivation or extrinsic motivation.

According to Hansen and Mowen (2000), the budget is a work plan prepared by the management of an organization that is measured in monetary units using certain standards in a certain period. The budget can be described as a managerial plan prepared using a long-term action plan and company objectives, as a manifestation of the work plan within a certain period. According to Anthony and Govindarajan (2001), the main objectives of budgeting are as follows: (1) improve the organization's strategic plan, (2) coordinate activities carried out by parts of the organization, (3) provide managers with responsibility for authorizing resource management organization and provide feedback to managers about their performance, (4) as commitment and agreement and basis for assessing manager's performance or performance.

Budgeting participation is a process that involves every member of the organization in preparing the budget and influencing the preparation of budget targets that are used to evaluate performance (Wong-On-Wing et. Al., 2010). According to Anthony and Govindarajan (2001), budgeting preparation has a positive influence on managerial performance, because when subordinates are involved in the budgeting process, there is a tendency for 
them to accept budget targets, and produce effective information exchange.

Tavakkoli Mohammadi \& Etemadi, (2007), Almasi, et al. (2015) suggests that budgeting is a manager's job and budget is a tool to control, motivate and assess performance. Many studies show that different levels of employee involvement in budgeting improve performance and achievement to organizational goals. Tsui (2001), Almasi et al. (2015) suggested that participation in budgeting was defined as the amount of involvement in budget preparation and development.

In a field study of budgetary practices and the relationship of input output budget systems, Hofstede (1968) generally concludes that participation increases the internalization of budgeted goals and thus can increase managers' motivation for better job performance. Hofstede (1968) suggested that participation would be satisfactory only when individuals felt that their input was validated by incorporation into the budgeting process.

According to Fölscher and Gay (2012 that public participation in budgeting means having access to information and opportunities for stakeholders, separated from the executive and legislature to become involved in the budget process.

Renzio \& Wehner, (2015) states that community participation in budgeting is still not well developed. The assumption of public participation is the belief that those affected by the decision have the right to be involved in the decision making process (IAP2). GIFT (2014) proposes a set of principles for public participation in policy and fiscal suspension that people can engage in government fiscal policy and in the budget process. In particular, public participation in government fiscal policy and the budget process is defined as the way citizens, civil society organizations, businesses and other non-state actors interact directly with public authorities on issues related to government taxation and revenue collection, resource allocation, spending management of public assets and liabilities "(GIFT, 2015, p. 1; Renzio \& Wehner, 2015).

\section{RESEARCH METHODS AND DATA COLLECTION}

This review is intended to show the relationship between the variables of budgetary participation and the performance of the sources of published articles. This review is based on empirical facts which is one of the efforts to summarize various quantitative research results. In the literature study,researchers collected many studies and summarized the results of the study, after which researchers were able to better identify relationships between variables and present aggregate data from the various primary studies.

\section{DISCUSSION}

Budget participation is how far the level of involvement and influence of individuals on in determining and preparing the budget in the division or section, both periodically and annually. Budget participation shows the extent to local government officials in understanding the budget by their work units and the influence of the objectives of their member accountability centers. While the performance of the government apparatus is a system that aims to assist leaders in assessing the achievement of a strategy through financial and non-financial measures. Participation in budgeting basically allows wherelower levels consider how budgets are formed (Hansen and Mowen, 2000).

The preparation of budget participation is an approach that can generally improve performance which in turn can increase organizational effectiveness. P artisipasi as a means of achieving goals, participation as well as a tool to integrate the needs of individuals and organizations. Good participation is expected to improve the performance, that is, when a purpose designed and approved in a participatory manner, then employees will internalize the goals set and have a sense of personal responsibility u ntuk achieve it, because they are involved in the budget preparation process. Brownell and Mcinnes (1986) found that high participation in budgeting can improve managerial performance. In public sector organizations.

Some research associated with budget participation and managerial performance which is an empirical facts, among others: Research Chong M. Lau (1997), shows that the relationship between leadership style and performance evaluative research findings on the managerial and budgetary participation and budget emphasis. These results indicate that high budget participation (regardless of budget emphasis) in situations of high task difficulty is associated with improved managerial performance. These results also show that a suitable combination of high budget emphasis and high participation is related to improving managerial performance in situations of low task uncertainty. This result is consistent with Brownell and Dunk (1991).

Study Mia (2010) studied the effect of participation in budgeting on performance management. Managerial attitudes toward work and company and motivation to work are studied in research. The results showed that the two variables moderate the influence of participation in budgeting. In particular, participation in the budgeting process for managers who have better attitudes or motivations is associated with improved performance, while the 
participation of managers who have bad attitudes or motivations is associated with different performance

Lopez et. al. (2009) studied participation in budgeting and executive job performance in South Korea and reported that overall results, US executives and Asian managers, research on participation in budgeting did not have a significant impact on their performance, but participation in budgeting had a significant positive impact on manager's performance indirectly through job satisfaction.

Research Almasih, et. al (2015), who investigated the impact of managerial participation in budgeting on management performance at Tehran Regional Electricity companies. The variables of this study are participation in budgeting, manager performance, adequacy of funding and resource allocation, job satisfaction, organizational commitment and organizational trust. His research findings indicate a significant correlation between variables of managerial participation in organizational budgeting and trust, adequacy of funding and allocation of resources and job satisfaction, manager's organizational trust in organizational commitment, organizational commitment and competence in the absorption of funds and optimal allocation of resources, and finally competency in funding and optimal allocation of manager resources as well as job satisfaction and management performance.

Fisher et.al., (2002) concerning budgetary participation and performance. His research findings indicate that budgetary participation has a significant effect on performance, because the budget is useful as a basis for performance evaluation. Research Alan S. Dunk, (1989) which shows that there are significant positive interactions and significant negative interactions between budgetary participation and budget emphasis that can affect performance. The findings of this study that performance is improved in high (low) participation conditions and low (high) budget emphas is.

Larissa's (2008) study explores the causes or antecedents of budget participation to fully understand the role of participation in the workplace.This study focuses on the reasons why superiors encourage their subordinates in budget participation and refers to several perspective theories including leadership theory, agency theory and justice organizations. The results of his research indicate that superiors encourage subordinate participation when the supervisor's leadership style is attentive. This implies that budgetary participation can mediate the relationship between leadership style and work outcomes. Results also show that superiors encourage participation when the objective budget is used in subordinate performance evaluation, superiors encourage participation because of concerns about organizational justice. This finding implies that participation budgets can mediate the relationship between the evaluative use of the budget and the results of work for which previous research has been linked to justice organizations.

In general, these empirical results can help develop a more complete budget participation role model in the workplace. Regarding leadership, results show that leaders with an attentive leadership style tend to promote subordinate participation in a budgeting arrangement. This finding also shows that budget participation can mediate the relationship between leadership style and work outcomes such as job satisfaction. These results also indicate that superiors promote subordinate participation when subordinates are evaluated using budget targets. The next finding is that budgetary participation can mediate the relationship between evaluative use of the budget and work outcomes. Larissa (2008) research also shows a significant relationship between evaluative use of budget and budget participation, this can reflect the desire of subordinates to participate in the budgeting process when the budget objectives are used to evaluate subordinates.

Research by Lorsu Wannarat, Tippawan (2016) shows that public participation in budgeting in the central government of Thailand adopted the Performance Based Budgeting System (SPBB) Strategy in the public sector in 2003. SPBB like the United Nations is now implemented in many countries, and it emphasizes the relationship between governments policy and budgeting. While Thailand has many laws and regulations related to public participation, there is no clear mechanism to support public participation in budgeting at the national level (interview with Deputy Budget Director).The government must follow a participatory approach by supporting community participation in policy formulation, public services, political decisions, examining state power, strengthening civil society, and public network organizations.

Leach-Lopez's (2007) study, which expanded the flow of participatory budget literature and specifically the work of Frucot and Shearon (1991).This study uses an expanded version of the path model introduced to this literature by Kren (1992) to examine and compare the relationship of budget participation performance to the level of US and Mexican middle managers. The extended path model allows examining both directly effecting budget participation on performance and the indirect effects of budget participation on performance carried out through job satisfaction and information relevant to work. The main finding of this study is that while there is a strong association between budgetary participation and performance for both US managers working in the US and Mexican managers working for controlled US maquiladera in Mexico, causal mechanisms that link budget participation with performance differ greatly 
between the two this group. The communication aspect of information from budgetary relations is participation with a much stronger performance among Mexican managers.

Research Chun, Loo Sin (1996), stated in his article that to examine the views of four groups of users for three important budget-related problems. The four user groups consist of accountants, managers, executives, and other professionals. Although there are several examples of real differences between different user groups, there is a general consensus that the main role of the budget in the company functions as forecasting and as a control device. The majority of respondents in each group felt that using the budget as a control tool would put pressure on them. Due to the pressure to meet the budget, real differences are revealed among different groups of users. Contrary to most of the available literature, all user groups want a greater level of participation by various levels of management. The general belief that accountants prefer a larger budget arrangement seems untrue.

This study uses the perspective of different user groups to investigate certain budget-related problems that have considerable potential importance for effective budget systems. Analysis of samples from the total industry as well as individual industry perspectives has revealed some important differences between this study and the materials discussed in the management accounting text. This research has provided some evidence that shows that there are fundamental disputes and inconsistencies in attitudes in some budget-related problems among user groups, it is very useful if factors contribute differently. Attitudes and perceptions of user groups can be identified as knowledge that can be done to help management to design and implement an effective budget system.

Research by Lau and Tan (2012), by reviewing the dependency area on the budget to evaluate employee performance. This research contributes in several ways. First, this updating of the area of traditional research makes it more relevant to the current debate about the use of nonfinancial financial measures in a multidimensional performance measurement system. Second, it examines the relationship between dependence on budget and budgetary participation in a way that is different from that used by previous studies. Budget participation is treated as a moderating variable, this study examines as a mediating variable. Specifically, this study hypothesizes that dependence on the budget as a performance measure influences the extent to which employee budgets participate. Third, combining new interest by management of accounting researchers in organizational justice into this area of research. This hypothesis shows that budgetary participation influences the extent to which employee perceptions of procedural justice, which in turn, influence employee satisfaction and performance. Structural equations from modeling results based on samples from 152 managers indicate that the use of budget targets for performance evaluation is positively related to employee satisfaction and performance. However, many of these effects are indirect through (1) budget participation and (2) procedural justice.

Research n Venkatesh and Blaskovich (2012), with the aim of providing empirical evidence about the relationship between budget participation, PsyCap, and job performance. As

expected, these findings show that budget participation is positively associated with PsyCap and that PsyCap positively related to performance. Venkatesh and Blaskovich (2012) also found support for the indirect effects of budgetary participation on performance through PsyCap. Furthermore, he added evidence that budgeting uses an intervening variable model to explain the results of previous studies that are unpredictable and inconsistent effects of motivation from budgetary participation. This endekatan P menga sumsikan that budgeting memengaruhi mental state, which in changing behavior (Covaleski et al. 2003). Different mental states have different behavioral effects, resulting in a positive relationship between budgeting and performance in some cases and negative ones in others. The aim is to identify mental states associated with positive results and design organizational practices to develop them. PsyCap is a development of positive psychology movements, which focus on developing individual strengths rather than their dysfunctions. This is in contrast to most previous research budget participation, which focuses on the negative consequences of participation

Research Kren, Leslie and S. Maiga, Adam. (2007), with the aim of expanding previous research by examining superior information asymmetries as intervening variables linking budgetary participation and concessions. The results show two offsetting participation effects on slack. a significant negative relationship between participation and concession is found to act through asymmetric information. Thus, managers reveal personal information during the budget process, reducing information asymmetry which then decreases budget slack. These results provide evidence of the inability of previous research to ensure a consistent direct relationship between budgetary participation and budget loosening.

Study Eker (2009) examined the relationship between participation in budgeting and work-related information on managerial performance andits results suggest that high-performance subjects tend to be more than low-performance subjects to apply 
participation in budgeting and work-related information. However, the results of this study indicate that the duration of reciprocal interaction is important and thus a higher interaction between budget participation and job-related information is associated with higher management performance.

\section{CONCLUSION}

The concept of budget participation is one of the concepts that is good enough to improve managerial performance in organizational management. The study of literature studies is based on empirical facts by examining some of the results of studies in international journals which show that participation in budgeting has a significant role and relationship to improving managerial performance. However, the concept of budget participation is not the only factor, but budget participation can be moderated or mediated with other variables such as psychological capital, job relevant information, knowledge and competence, leadership style, motivation, and others.

\section{REFERENCES}

[1] Alan S. Dunk, (1989). Budget Emphasis, Budgetary Participation And Managerial Performance: A Note

*. Printed in Great Britain Pergamon plc Accounting Organization and Society, Vol. 14, No.4, pp. 321324, 1989.

[2] Almasi, Hasan, et al. (2015). Budgetary participation and managerial performance: The impact of information and environmental volatility. Management Science Letters 5 (2015) 843-854

[3] Brownell, P., (1982).The Role of Data Accounting in Performance Evaluation, Budgetary Participation, and Organizational Effectiveness, Journal of Accounting Research (Spring 1982) pp. 12-27.

[4] Brownell, P. \& Hirst, M., (1986). Reliance on Accounting Information, Budgetary Participation, and Task Uncertainty: Tests of Threeway Interaction, Journal of Accounting Research (Autumn 1986) pp. 241- 249.

[5] Chow, chee w./cooper, Jean c./Waller, william s. (1988), "Participative Budgeting: Effects of A Truth-Inducing Pay Scheme and Information Asymetry On Slack And Performance," The Accounting Review, Vol. LXIII, No.1, January, 111122.

[6] Chun, Loo Sin . (1996) Views of Malaysian UsersGroups to the Role of Budget, Asian Budget Pressure and Participation. Review of Accounting Volume 4, Number 2,1996

[7] Chong M. Lau, (1997).The interactive effect of budget emphasis, participation and task difficulty on managerial performance: a cross-cultural study.The University of Western Australia, Nedlands, Perth,. Auditing \& Accountability Journal, Vol. 10 No. 2, 1997, pp. 175-197. (C) MCB University Press, 0951-3574

[8] Fisher, J., JR Frederickson, and SA Peffer, (2002). "The Effect of Information Asymmetry on Negotiated Budgets: An Empirical Investigation." Accounting, Organizations and Society Vol. 27, pp. 27 - 43.

[9] Fölscher, A. (2007). Participatory budgeting in central and eastern Europe. In A. Shah (Ed.), Participatory budgeting (pp. 127-156). Washington, $D C$ : The World Bank.

[10] Fölscher, A., \& Gay, E. (2012). Fiscal transparency and participation in Africa: A study report. Pretoria, South Africa: The Collaboration Africa Budget Reform Initiative (CABRI) .. $\quad$ Retrieved from http://zunia.org/sites/default/ files / media / node-files / ca / 453750_cabri_fiscal_transpar ency_english_web.pdf

[11] GIFT. (2015). The time is now: Advancing public participation in government fiscal policy and budget-making, high level synthesis of case studies on Brazil, Canada, Croatia, Kenya, Mexico, Philippines, South Africa, South Korea. Retrieved fromhttp://www.fiscaltransparency.net/eng/principle s.php

[12] Govindarajan, V. (2001), "Impact of Participation in the Budgetary Process on Managerial Attitudes and Performance: Universalistic and Contingency Perspectives, " Decision Sciences : 496-516.

[13] Hansen and Mowen, 2000, Management Accounting, Erlangga, Jakarta.

[14] Hansen, Don, R., and MM Mowen, 2000. Management Accounting. Fourth Edition, Prentice Hall, New Jersey.

[15] Harianty, Widi (2015). Pluriform motivation as antecedent and its relationships to budgeting participation and managerial performance (Empirical Study on Manufacturing Companies listed on Indonesian Stock Exchange). 2nd Global Conference on Business and Social Science-2015, GCBSS-2015, 17-18 September 2015, Bali, Indonesia. Procedia - Social and Behavioral Sciences 211 (2015) 836 - 843

[16] Hofstede, GH (1968). The Game of Budget Control. London

[17] Hopwood, AG, (1972). An Empirical Study of the Role of Data Accounting in Performance Evaluation, Journal of Accounting Research (Supplement 1972) pp. 156 i 82.

[18] Ji Hyung Park (2018): Does Citizen Participation Matter to Performance - Based Budgeting ?, Public 
Performance and Management Review, DOI: 10.1080 / 15309576.2018.1437050

[19] Kren, Leslie and S. Maiga, Adam. (2007). The Intervening Effect of Information Asymmetry on Budget Participation and Segment Slack. Advances in Management Accounting, Volume 16, 141-157 Copyright 2007 by Elsevier Ltd. All rights to reproduction in any form reserved ISSN: 1474-7871 / doi: 10.1016 / S1474-7871 (07) 16004-4

[20] Kren, L. (1992). Budgetary Participation and Managerial Performance: The Impact of Information and Environmental Volatility, The Accounting Review, Milwaukee

[21] Larissa Kyj and Robert J. Parker (2008) Antecedents of Budget Participation: Leadership Style, Information Asymmetry, and Evaluative Use of Budget. A Journal of Accounting, Finance and Business Studies.ABACUS, Vol.44, No.4, 2008 doi: 10.1111 / j.1467-6281.2008.00270.x

[22] Lau, Chong M. and Tan, Sharon LC (2012). Budget Targets As Performance Measures: The Mediating Role of Participation and Procedural Fairness. Advances in Management Accounting, Volume 20, 151-185 Copyright 2012 by Emerald Group Publishing Limited All rights to reproduction in any form reserved ISSN: 1474-7871 / doi: 10.1108 / S1474-7871 (2012) 0000020013

[23] Lau, Chong M./buckland, Christen (2000), "Budget Emphasis, Task Difficulty and Performance: The Effect of Diversity Within Culture," Accounting and Business Research, 31: 37-55.

[24] Lau, chong m. / Buckland, christen (2001), "Budgeting-The Role of Trust and Participation: A Research Note," Abacus, 37/3: 369-386.

[25] Leach-Lo'pez. (2007). Differences in the Role of Job-Relevant Information in the Budget Participation-Performance Relationship among US and Mexican Managers: A Question of Culture or Communication./ Journal of Management Accounting Research Volume Nineteen 2007 pp. 105-136

[26] Lorsuwannarat, Tippawan (2016): Public Participation in Budgeting: The New Path of Budget Reform in Thailand, International Journal of Public Administration, DOI: $\quad 10.1080$ / 01900692.2015.1126730

[27] Mardiasmo, (2001), Supervision, Control and Examination of Government Performance in the Implementation of Regional Autonomy, Journal of Business and Accounting, August pp. 441-456.

[28] -------, (2006), Public Sector Accounting, Andi Offset, Yogyakarta.

[29] Mia, Lokman and Patiar, Anoop. (2002). The Interactive Effect of Superior-Subordinate
Relationship and Budget Participation on Managerial Performance in the Industry Hotels: An Exploratory Study.Journal of Hospitality \& Tourism Research, Vol.26, No.3, August 2002, 235-257 (C) 2002 International Council on Hotel, Restaurant and Institutional Education

[30] Murray, D. (1990), "The Performance Effects of Participative Budgeting: An Integration of Intervening and Moderating Variables," Behavioral Research in Accounting , 2/2: 104- 123.

[31] Otley, DT, (1978). Budget Use and Managerial Performance, Journal of Accounting Research (Spring 1978) pp. 122-149.

[32] Renzio, P., \& Wehner, J. (2015). The impacts of fiscal openness: A review of the evidence. New York: SSRN. Retrieved from http://ssrn.com/abstract=2602439

[33] Siegers, V. 2004. Hubungan Partisipasi Anggaran dengan Informasi Job Relevant, serta Pengaruhnya terhadap Kepuasan Kerja dan Kinerja Manajerial di lingkungan Pemerintah Daerah.Tesis S2 Universitas Gajah mada. Yogyakarta.

[34] Venkatesh, Roopa and Blaskovich, Jennifer. (2012).The Mediating Effect of Psychological Capital on the Budget Participation-Job Performance Relationship. Journal Of Management Accounting Research American Accounting Association Vol. 24 DOI: 10.2308/jmar-50202 2012 pp. 159-175

[35] Wong-On-Wing, B., Lan Guo, dan Gladie Lui, (2010). "Intrinsic and Extrinsic Motivation and Participation in Budgeting : Antecedents and Consequences. 'Behavioral Research in Accounting Volume 22. 